\title{
Trace element contamination in rice and its potential health risks to consumers in North-Central Vietnam
}

\section{Thao Le Thanh}

Phenikaa University

Kyoung-Woong Kim

Gwangju Institute of Science and Technology

\section{Dinh Quoc Nguyen}

Vietnam Institute of Geosciences and Mineral Resources

Huong Thi Thuy Ngo ( $\nabla$ huong.ngothithuy@phenikaa-uni.edu.vn )

Phenikaa University https://orcid.org/0000-0002-1894-2624

\section{Research Article}

Keywords: Trace elements, Rice, North-Central Vietnam, Health risk assessments

Posted Date: January 17th, 2022

DOI: https://doi.org/10.21203/rs.3.rs-1219635/v1

License: (a) (i) This work is licensed under a Creative Commons Attribution 4.0 International License. Read Full License 


\section{Abstract}

This study assessed the potential health risks of five elements $(\mathrm{Ni}, \mathrm{Cr}, \mathrm{As}, \mathrm{Cd}$, and $\mathrm{Pb})$ in rice collected from three provinces in North-Central Vietnam, Thanh Hoa, Nghe An, and Ha Tinh. These provinces comprise areas with and/or without mining and industrial activities, focusing on two local population groups (adults and children under five years old). Trace elements were determined by an inductively coupled plasma mass spectrometry (ICP-MS). The potential health risks were evaluated for different age groups using the estimated daily intakes (EDI), target hazard quotients (THQ), non-carcinogenic hazard quotients ( $\mathrm{HI}$ ), and target carcinogenic risks (TR). The highest element levels ( $\mathrm{mg} \mathrm{kg}^{-1} \mathrm{dry}$ weight) were observed in Thanh Hoa for $\mathrm{Cr}(0.30 \pm 0.106)$, As $(0.13 \pm 0.034)$ and for $\mathrm{Pb}(0.05 \pm 0.015)$, and in $\mathrm{Ha}$ Tinh for $\mathrm{Cd}(0.06 \pm 0.022)$. The highest estimated daily intakes (EDIs) of $\mathrm{Cr}\left(4.1 \mu \mathrm{g} \mathrm{d}^{-1}\right), \mathrm{Ni}\left(3.3 \mu \mathrm{g} \mathrm{d}^{-1}\right), \mathrm{As}(2.3$ $\left.\mu \mathrm{g} \mathrm{d}^{-1}\right), \mathrm{Cd}\left(1.2 \mu \mathrm{g} \mathrm{d}^{-1}\right)$, and $\mathrm{Pb}\left(0.32 \mu \mathrm{g} \mathrm{d}^{-1}\right)$ were observed in several sites. The THQ of rice in three provinces showed a risk trend in the following order: Thanh $\mathrm{Hoa}>\mathrm{Ha}$ Tinh $>$ Nghe An. The Hls of trace elements revealed that As is a key component, with $\mathrm{Cr}$ and $\mathrm{Cd}$ as secondary risk factors in adults and children, with HIs being 1.5 times higher in girls under five than in other groups. The TR of Ni was much greater than that of $\mathrm{Pb}$, and it was higher in children than adults, with the maximum risk levels of $\mathrm{Ni}$ and $\mathrm{Pb}$ were $3.0 \times 10^{-3}$ and $2.7 \times 10^{-6}$ for baby girls under the age of five in Ha Tinh and Thanh Hoa, respectively. The risk assessment of trace element dietary intake suggests that rice consumption poses significant health risks to the local population, both in non-carcinogenic and carcinogenic effects.

\section{Introduction}

Trace elements like lead (Pb), cadmium (Cd), arsenic (As), chromium ( $\mathrm{Cr}$ ), and nickel (Ni) can all be found in nature. However, as human activities have increased, particularly mining and industrial processing, these trace elements have become a global environmental hazard (Fan et al., 2017; Zhuang et al., 2009). Because of their high toxicity, wide distribution, persistence, and transferability to plants, trace element contamination of the environment, particularly soil, has been one of the most challenging pollution concerns and can lead to various diseases (Rodriguez et al., 2007; Huang et al., 2007; Qu et al., 2015). Although some trace elements in the soils are required for plant and crop growth to some extent, others are highly toxic to humans. Toxic trace elements in the soil can be taken up by plants and accumulated in higher concentrations, eventually making their way into the human body via the food chain (Qu et al., 2015; Xiao et al., 2017).

Because rice is a staple food in many nations, especially in Asia, trace element contamination in rice has caught the interest of researchers worldwide (Shimbo et al., 2001; Zarcinas et al., 2004). Low and high amounts of $\mathrm{As}, \mathrm{Pb}, \mathrm{Cd}, \mathrm{Cr}$, and $\mathrm{Ni}$ exposure can have carcinogenic and non-carcinogenic consequences. Skin, lung, kidney, and bladder malignancies have been linked to As poisoning (Fan et al., 2017; Bui et al., 2016). Toxic exposure to $\mathrm{Cd}$ and $\mathrm{Pb}$ has been linked to lung, prostate, and kidney cancers (Chen et al., 2019; Bui et al., 2020). The maximum limits of trace elements in rice grains in the world set to protect 
humans from eating trace elements in their diet Codex Alimentarius Commission (CAC) Standard (CAC, 2019), are $0.2 \mathrm{mgkg}^{-1}$ for $\mathrm{As}$ and $\mathrm{Pb}, 0.04 \mathrm{mgkg}^{-1}$ for $\mathrm{Cd}, 1.3 \mathrm{mgkg}^{-1}$ for $\mathrm{Cr}$ and $10 \mathrm{mgkg}^{-1}$ for Ni.

Many trace elements from industrial or mining sources have infiltrated crop tissues because of crop absorption from contaminated soils, wastewater irrigation, and polluted air during economic development (Huang et al., 2007; Sridhara Chary et al., 2008). A wide range of minerals containing various elements (e.g., antimony, chromite, copper, tin, tungsten) have been discovered in Vietnam, and numerous metalliferous mines have been established throughout the country. Despite the fact that mining areas and industrial zones were designed to prevent the release of tailings, wastewater, and solid waste into the surrounding environment, trace element pollution occurred in lower streams and farmland areas (Kien et al., 2010). Cd, $\mathrm{Pb}$, and As levels in soil and water affected by $\mathrm{Pb}-\mathrm{Zn}$ mining activities in Thai Nguyen and Bac Kan provinces are incredibly high (Bui et al., 2016; Nguyen et al., 2011). The provinces of Thanh Hoa, Nghe An, and $\mathrm{Ha}$ Tinh, located in north-central Vietnam, have a variety of mineral resources and industrial zones. According to Khoi (Khôi, 2014), mining sources in Thanh Hoa include chromite, tungsten, quartgold, industrial minerals, graphite, construction materials, and bauxite in Nghe An. These provinces also have high levels of local rice production; hence food safety concerns due to trace element contamination have been addressed.

Some studies of toxic trace elements in rice and soil, such as $\mathrm{Cd}$, As, and $\mathrm{Pb}$, have focused on single metals or sampling sites. Furthermore, the cancer risk and health risk factors associated with various trace elements in multiple regions have not been thoroughly assessed, particularly in Vietnam. Thus, the risk posed by concentrations of five toxic trace elements $(\mathrm{Pb}, \mathrm{Cd}, \mathrm{As}, \mathrm{Ni}$, and $\mathrm{Cr}$ ) in three north-central provinces of Vietnam was assessed in this study. Data from mining and industrial regions are compared to those without mining and industrial activities. The health risk to residents was evaluated using potential non-carcinogenic ( $\mathrm{HQ}, \mathrm{HI})$ and carcinogenic risk (TR) indices. This study provides a database on the potential health risk of trace elements in rice that could be useful for trace element contamination control and risk management in other parts of the world.

\section{Materials And Method 2.1. Sampling sites}

Sampling sites were chosen in ten districts across three provinces: Thanh Hoa, Ha Tinh, and Nghe An (Fig. 1). In Thanh Hoa province, sampling locations were near mining sites, local industrial zones, and the coastal plain. The sampling locations in Nghe An were along with the Lam river's upstream, whereas those in Ha Tinh were near the Lam river's downstream and the Duc Tho or Vung Ang industrial zones.

\subsection{Sampling and pre-treatment}

The rice grown at the studied locations, which accounted for regional consumption, was harvested in November 2020. All samples were dried in a vacuum oven at $70^{\circ} \mathrm{C}$ for at least 72 hours. After that, the 
samples were then reweighed, pulverized, and stored in food-grade zip-bags for further processing and analysis.

\subsection{Sample analysis}

A $0.5 \mathrm{~g}$ aliquot of each rice sample was digested with $4 \mathrm{ml}$ of $\mathrm{HNO}_{3}(70 \%$, Electronic Grade, Duksan, Korea) using a microwave digestion system (Multiwave 7000, Anton Paar). The digestion program for high organic compounds was listed as follows: stage $1: 250^{\circ} \mathrm{C}$ for 20 minutes, stage $2: 250^{\circ} \mathrm{C}$ for 15 minutes. After that, the samples were filtered and diluted with distilled water $\left(>18 \mathrm{M} \Omega \mathrm{cm}^{-1}\right)$. The trace elements in rice samples were analyzed using inductively coupled plasma mass spectrometry (ICP-MS, Agilent 7900).

\subsection{Quality assurance and quality control}

Appropriate quality assurance procedures and precautions were carried out to ensure the reliability of the results. Double distilled deionized water was used throughout the study. The glassware had been thoroughly cleaned, and the reagents were of analytical grade. Blank determinations of reagents were used to correct the instrument readings. A recovery study was performed to validate the analytical procedure, which involved spiking and homogenizing several previously analyzed samples with varying quantities of standard solutions. Each sample was tested five times in total.

\subsection{Data analysis}

\subsubsection{Estimated daily intakes (EDIs) of trace elements}

The EDIs of trace elements $(\mathrm{Cr}, \mathrm{Ni}, \mathrm{As}, \mathrm{Cd}$, and $\mathrm{Pb})$ varied depending on the metal concentration in rice and the amount of rice consumed. The following equation was used to calculate the EDIs of trace elements for the locals:

$E D I=\frac{M_{C} \times I R}{B_{W}}($ Eq. 1)

where $M_{c}\left(\mu g^{-1}\right)$ is the concentration of trace elements in contaminated rice; IR represents the average daily consumption of rice; Bw is the body weight. Based on the data survey from FAOSTAT (FAO, 2018), the adults in Vietnam had an average consumption per person $(59.4 \mathrm{~kg}$ and $50.3 \mathrm{~kg}$ in body weights of males and females, respectively) of $325.5 \mathrm{~g} \mathrm{day}^{-1}$ (Nutrition, 2012); whereas the investigated ones in children under five years old (16.4 kg and $15.2 \mathrm{~kg}$ in body weights of boy and girl, respectively) was $205 \mathrm{~g}$ day $^{-1}$ (Nguyen et al., 2021).

\subsubsection{Target hazard quotients (THQ)}

The health risks associated with rice consumption by residents were assessed using the THQ. If the ratio is less than one, the exposed population is unlikely to experience apparent adverse health effects, whereas the rice consumers may face a potential health risk if the ratio is higher than one. The method 
for estimating potential health risk with THQ was described in Regional Screening Levels (RSLs) Equations (US EPA, 2021) and Chien's study (Chien et al., 2002) and is based on the equation below:

$T H Q=\frac{M_{C} \times I R \times 10^{-3} \times E f \times E d}{R f D \times B_{W} \times A T n}($ Eq. 2)

Where:

THQ is the target hazard quotient; $\mathrm{Ef}$ is exposure frequency ( 365 days year ${ }^{-1}$ ); Ed is total exposure duration (70 years); IR is the daily ingestion rate for locals (g person ${ }^{-1} d^{-1}$ ); $M_{c}$ is metal concentration in food $\left(\mu \mathrm{g} \mathrm{g}^{-1}\right)$; RfD is the oral reference dose $\left(\mathrm{mg} \mathrm{kg}^{-1} \mathrm{~d}^{-1}\right) ; B_{\mathrm{w}}$ is the average body weight; ATn is the average time for non-carcinogens (365 days year ${ }^{-1} \times$ number of exposure years, assuming 70 years in this study). Oral reference doses were based on $3 \times 10^{-4}, 10^{-3}, 1.1 \times 10^{-2}, 3 \times 10^{-3} \mathrm{mg} \mathrm{kg}^{-1} \mathrm{~d}^{-1}$ for As, Cd, $\mathrm{Ni}$, and $\mathrm{Cr}$, respectively (US EPA, 2014).

There is no RfD for $\mathrm{Pb}$, so the THQ for $\mathrm{Pb}$ was calculated as follows:

$T H Q=\frac{M_{C}}{M R L}($ Eq. 3)

Where: the MRL is the maximum limit of $\mathrm{Pb}$ in rice grains acquired by the Codex Alimentarius Commission Standard (CAC, 2019).

\subsubsection{Hazard index (HI)}

The $\mathrm{HI}$ is the sum of the individual target hazard quotient for the tested elements from rice. According to the $\mathrm{HI}$, eating rice may simultaneously be exposed to several potentially toxic elements, the cumulative effects of multiple elements from rice consumption may result in adverse health effects. If the HI exceeds one, there is a potential risk of non-carcinogenic health effects. The HI equation is as follows:

$H I=\sum_{n=1}^{i} T H Q_{n}$ (Eq. 4)

\subsubsection{Target cancer risks}

The target cancer risk (TR) is used to assess the potential risk associated with carcinogenic agent exposure over a lifetime. An oral slope factor is used instead of an oral reference dose, which is used to determine THQ. This factor, along with the carcinogen dose, determines the likelihood of cancer risk over the lifetime of the exposed individual. TR can be calculated using the following formula:

$T R=\frac{E f \times E d \times I R \times M C \times C P S_{0}}{B W_{a} \times A T_{C}} \times 10^{-3}($ Eq. 5)

Where: Ef is the exposure frequency; Ed is the exposure duration (70 yrs); IR is the food ingestion rate in grams per day for the rice; $\mathrm{Mc}$ is the concentration in a wet weight of the trace element in the given rice; CPSo is the oral carcinogenic slope factor for $\mathrm{Pb}, \mathrm{As}, \mathrm{Ni}$ and $\mathrm{Cr}$ of $8.5 \times 10^{-3}, 1.5,0.91$, and 0.5 
$\mathrm{mgkg}^{-1}$ day $^{-1}$, respectively; $B_{\mathrm{w}}$ is the reference body weight; ATc is the averaged exposure time to the carcinogen ( 365 days $\times 70 \mathrm{yrs}$ ) and $10^{-3}$ is the unit conversion factor.

\section{Results And Discussion}

\subsection{Trace elements in rice grown in study sites}

The average trace element concentrations in rice samples were highest for $\mathrm{Ni}$, followed by $\mathrm{Cr}$, As, then $\mathrm{Cd}$, and lowest for $\mathrm{Pb}$ (Table 1; Fig. 2). Thanh Hoa had the highest levels of trace element contamination in rice, particularly $\mathrm{Cr}$, As, and $\mathrm{Pb}$, followed by Ha Tinh, and Nghe An had the lowest levels (Table 1). 
Table 1

Concentrations of $\mathrm{Cr}$, Ni Cd, $\mathrm{Pb}$, and As in rice collected from Thanh Hoa, Ha Tinh and Nghe An provinces. Values are expressed as average \pm standard deviation

\begin{tabular}{|c|c|c|c|c|c|c|}
\hline \multicolumn{2}{|l|}{ Province } & \multirow{2}{*}{$\begin{array}{l}\text { Cr } \\
0.43 \pm 0.17\end{array}$} & \multirow{2}{*}{$\begin{array}{l}\mathbf{N i} \\
0.27 \pm \\
0.071\end{array}$} & \multirow{2}{*}{$\begin{array}{l}\text { As } \\
0.13 \pm \\
0.034\end{array}$} & \multirow{2}{*}{$\begin{array}{l}\text { Cd } \\
0.013 \pm \\
0.004\end{array}$} & \multirow{2}{*}{$\begin{array}{l}\mathrm{Pb} \\
0.05 \pm \\
0.02\end{array}$} \\
\hline $\begin{array}{l}\text { Thanh } \\
\text { Hoa }\end{array}$ & Quang Xuong & & & & & \\
\hline & Bim Son & $0.39 \pm 0.20$ & $\begin{array}{l}0.29 \pm \\
0.048\end{array}$ & $\begin{array}{l}0.19 \pm \\
0.023\end{array}$ & $\begin{array}{l}0.022 \pm \\
0.005\end{array}$ & $\begin{array}{l}0.011 \pm \\
0.002\end{array}$ \\
\hline & Nghi Son & $\begin{array}{l}0.091 \pm \\
0.058\end{array}$ & $\begin{array}{l}0.12 \pm \\
0.028\end{array}$ & $\begin{array}{l}0.21 \pm \\
0.018\end{array}$ & $\begin{array}{l}0.007 \pm \\
0.001\end{array}$ & $\begin{array}{l}0.010 \pm \\
0.003\end{array}$ \\
\hline & Average & $0.30 \pm 0.11$ & $\begin{array}{l}0.22 \pm \\
0.054\end{array}$ & $\begin{array}{l}0.17 \pm \\
0.025\end{array}$ & $\begin{array}{l}0.014 \pm \\
0.005\end{array}$ & $\begin{array}{l}0.024 \pm \\
0.013\end{array}$ \\
\hline \multirow[t]{4}{*}{ Ha Tinh } & Nghi Xuan & $\begin{array}{l}0.034 \pm \\
0.0051\end{array}$ & $\begin{array}{l}0.23 \pm \\
0.065\end{array}$ & $\begin{array}{l}0.14 \pm \\
0.008\end{array}$ & $\begin{array}{l}0.061 \pm \\
0.022\end{array}$ & $\begin{array}{l}0.013 \pm \\
0.001\end{array}$ \\
\hline & Duc Tho & $\begin{array}{l}0.024 \pm \\
0.0022\end{array}$ & $\begin{array}{l}0.16 \pm \\
0.010\end{array}$ & $\begin{array}{l}0.12 \pm \\
0.020\end{array}$ & $\begin{array}{l}0.091 \pm \\
0.018\end{array}$ & $\begin{array}{l}0.006 \pm \\
0.002\end{array}$ \\
\hline & Ky Anh & $\begin{array}{l}0.028 \pm \\
0.0051\end{array}$ & $\begin{array}{l}0.36 \pm \\
0.071\end{array}$ & $\begin{array}{l}0.16 \pm \\
0.011\end{array}$ & $\begin{array}{l}0.11 \pm \\
0.039\end{array}$ & $\begin{array}{l}0.013 \pm \\
0.003\end{array}$ \\
\hline & Average & $\begin{array}{l}0.029 \pm \\
0.0030\end{array}$ & $\begin{array}{l}0.25 \pm \\
0.058\end{array}$ & $\begin{array}{l}0.14 \pm \\
0.014\end{array}$ & $\begin{array}{l}0.088 \pm \\
0.015\end{array}$ & $\begin{array}{l}0.011 \pm \\
0.002\end{array}$ \\
\hline \multirow[t]{5}{*}{ Nghe An } & Nghia Dan & $\begin{array}{l}0.045 \pm \\
0.013\end{array}$ & $\begin{array}{l}0.15 \pm \\
0.044\end{array}$ & $\begin{array}{l}0.078 \pm \\
0.008\end{array}$ & $\begin{array}{l}0.015 \pm \\
0.011\end{array}$ & $\begin{array}{l}0.007 \pm \\
0.001\end{array}$ \\
\hline & Do Luong & $\begin{array}{l}0.037 \pm \\
0.010\end{array}$ & $\begin{array}{l}0.17 \pm \\
0.039\end{array}$ & $\begin{array}{l}0.15 \pm \\
0.008\end{array}$ & $\begin{array}{l}0.045 \pm \\
0.012\end{array}$ & $\begin{array}{l}0.010 \pm \\
0.002\end{array}$ \\
\hline & Hung Nguyen & $\begin{array}{l}0.026 \pm \\
0.004\end{array}$ & $\begin{array}{l}0.36 \pm \\
0.092\end{array}$ & $\begin{array}{l}0.16 \pm \\
0.011\end{array}$ & $\begin{array}{l}0.097 \pm \\
0.030\end{array}$ & $\begin{array}{l}0.014 \pm \\
0.003\end{array}$ \\
\hline & Thanh Chuong & $\begin{array}{l}0.038 \pm \\
0.004\end{array}$ & $\begin{array}{l}0.18 \pm \\
0.027\end{array}$ & $\begin{array}{l}0.18 \pm \\
0.006\end{array}$ & $\begin{array}{l}0.038 \pm \\
0.013\end{array}$ & $\begin{array}{l}0.007 \pm \\
0.001\end{array}$ \\
\hline & Average & $\begin{array}{l}0.036 \pm \\
0.004\end{array}$ & $\begin{array}{l}0.21 \pm \\
0.048\end{array}$ & $\begin{array}{l}0.14 \pm \\
0.021\end{array}$ & $\begin{array}{l}0.049 \pm \\
0.017\end{array}$ & $\begin{array}{l}0.009 \pm \\
0.002\end{array}$ \\
\hline \multicolumn{2}{|c|}{$\begin{array}{l}\text { WHO permissible limits (CAC, } \\
2019 \text { ) }\end{array}$} & 1.30 & 10 & 0.2 & 0.04 & 0.2 \\
\hline
\end{tabular}

High concentrations of $\mathrm{Ni}\left(\mathrm{mg} \mathrm{kg}^{-1} \mathrm{dw}\right)$ were found in Hung Nguyen (0.36 \pm 0.092$)$, Nghe An, in Ky Anh $(0.35 \pm 0.071)$ and Nghi Xuan (0.23 \pm 0.065$)$, Ha Tinh, and in Bim Son (0.29 \pm 0.045$)$ and Quang Xuong $(0.27 \pm 0.071)$, Thanh Hoa. The highest concentrations of $\mathrm{Cr}\left(\mathrm{mg} \mathrm{kg}^{-1} \mathrm{dw}\right)$ were found in Thanh Hoa, with an average concentration of $0.30 \pm 0.11$, which was about ten times higher than in other provinces (Nghe An: $0.036 \pm 0.004$; and Ha Tinh: $0.029 \pm 0.03$; Table 1). Cr concentrations in Quang Xuong, Bim Son, and Nghi Son were $0.43 \pm 0.17,0.39 \pm 0.20$, and $0.091 \pm 0.058$, respectively (Fig. 2, Table 1). 
According to the previous study (Huang et al., 2007), Cr was found in rice at relatively high concentrations of $0.29 \pm 0.14$ (in Changshu) and 0.107 (Taizhou). This study indicated that industrial activities might have been influenced the concentrations of $\mathrm{Cr}$ in rice from Changshu's area. According to Kien (Kien et al., 2010), the Co Dinh chromite mine (Thanh Hoa) contaminated lowland paddy fields with $\mathrm{Cr}, \mathrm{Ni}$, and $\mathrm{Co}$, posing significant health risks through agricultural products. He also stated that water contaminated with $\mathrm{Cr}$ and $\mathrm{Ni}$ in the mining area could pollute nearby rivers. In our study, the $\mathrm{Cr}$ and $\mathrm{Ni}$ levels were well correlated with industrial and mining activities. Especially in Thanh Hoa, the ultramafic outcrops are rarely exposed and severely weathered; hence, trace elements are diluted and sedimented in the Ma River delta plain, where Quang Xuong and Bim Son are located. The distances between these two districts and the chromite mine (Co Dinh) are approximately $16 \mathrm{~km}$ and $50 \mathrm{~km}$, respectively. Additionally, several sites of construction material mining (Ky Anh and Nghi Xuan) and industrial activities may also be factors in the high concentration of trace elements in rice from Hung Nguyen district, Nghe An province (about 12$15 \mathrm{~km}$ to the industrial zones of Bac Vinh and Nam Cam), or from Ky Anh district, Ha Tinh province (next to the industrial zones of Vung Ang), and Bim Son district, Thanh Hoa province (less than $10 \mathrm{~km}$ from Bim Son industrial zone).

The average concentrations of $\mathrm{As}\left(\mathrm{mg} \mathrm{kg}^{-1} \mathrm{dw}\right)$ in rice samples collected from Thanh Hoa, Ha Tinh, and Nghe An were $0.173 \pm 0.025,0.139 \pm 0.014,0.139 \pm 0.021$, respectively. There have been several studies that have investigated the As contents in rice, and our findings were comparable to those reported in other studies conducted in the Red River Basin (from 0.053 to $0.469 \mathrm{mg} \mathrm{kg}^{-1} \mathrm{dw}$ ) (Tran et al., 2020) and near the mining sites $\left(0.052 \mathrm{mg} \mathrm{kg}^{-1}\right.$ to $0.328 \mathrm{mg} \mathrm{kg}^{-1} \mathrm{dw}$ ) (Chu et al., 2021). However, the average As concentration in the current study was less than $0.2 \mathrm{mg} \mathrm{kg}^{-1}$ (the threshold recommended by the FAOWHO Codex Alimentarius Commission (CAC, 2019), and the As contents of samples collected from Bim Son and Nghi Son were slightly higher. According to Tran's study (Tran et al., 2020), grain As content gradually increases from mountainous and hilly regions to lowland (coastal) regions, whereas soil As content does not. In other words, the high concentration of As in rice could be due to factors other than natural sources, such as anthropogenic activities and especially the bioavailable forms of this element. Besides, mining activity could be a significant factor in rice's high As content (Chu et al., 2021). Irrigation with arsenic-contaminated water in rice fields raises the concentration of As in the topsoil and its bioavailability to rice crops (Azam et al., 2016). As accumulation in rice grains is increased due to As in paddy rice's high bioavailability and mobility (Xu et al., 2008). In our study, the lowest As content was found in samples from Nghia Dan, which is located in the highlands and was far from industrial zones; whereas, high As levels were found in samples from Bim Son (near the Bim Son industrial zone), Nghi Son (near the Nghi Son refinery and petrochemical factory, Nghi Son iron and steel company, Nghi Son Cement company), and Ky Anh (right next to the Vung Ang industrial park-seaport complex).

The highest Cd levels ( $\mathrm{mg} \mathrm{kg}^{-1} \mathrm{dw}$ ) were found in Ha Tinh (0.061 \pm 0.022 to $\left.0.11 \pm 0.039\right)$, followed by Nghe An (0.015 \pm 0.011 to $0.097 \pm 0.030)$, and Thanh Hoa (0.007 \pm 0.001 to $0.022 \pm 0.005)$ (Table 1 , Fig. 2). Interestingly, $60 \%$ and $40 \%$ of the rice samples collected from Ha Tinh and Nghe An, respectively, contained Cd levels above CODEX permissible limits (CAC, 2019). In comparison to the present findings, 
some studies have found lower Cd concentrations in rice, e.g., the Red River basin $\left(0.033 \mathrm{mg} \mathrm{kg}^{-1} \mathrm{dw}\right)$ (Bui et al., 2016) and Changshu city $\left(0.019 \mathrm{mg} \mathrm{kg}^{-1} \mathrm{dw}\right.$ ) (Hang et al., 2009). However, others reported that the $\mathrm{Cd}$ concentrations in rice cultivated from the mining sites in Hunan province $\left(0.103 \mathrm{mg} \mathrm{kg}^{-1} \mathrm{dw}\right)($ Fan et al., 2017), the Yangzhong district $\left(0.224 \mathrm{mg} \mathrm{kg}^{-1} \mathrm{dw}\right.$ ) (Hang et al., 2009) and the Jin-Qu basin (0.163 $\mathrm{mg} \mathrm{kg}^{-1} \mathrm{dw}$ ) (Guo et al., 2020) were higher than our data.

$\mathrm{Pb}$ concentrations ( $\mathrm{mg} \mathrm{kg}^{-1} \mathrm{dw}$ ) in the rice samples ranged considerably from $0.006 \pm 0.002$ (Duc Tho) to $0.050 \pm 0.015$ (Quang Xuong). Thanh Hoa's average $\mathrm{Pb}$ content was at least twice that of $\mathrm{Ha}$ Tinh and Nghe An. In comparison to other studies from the Red River Delta ( $0.075 \mathrm{mg} \mathrm{kg}^{-1} \mathrm{dw}$ ) (Chu et al., 2021), the Yangtze River Delta (0.957 mg kg-1 dw) (Hang et al., 2009), and the Jin-Qu Basin $\left(0.148 \mathrm{mg} \mathrm{kg}^{-1} \mathrm{dw}\right.$ ) (Guo et al., 2020), the current results showed lower Pb levels.

Mining and industrial activities could be the sources of $\mathrm{Pb}$ and $\mathrm{Cd}$ in rice grain. Another report (Hang et al., 2009) found that the erosion of these metals from e-waste recycling activities could be discharged into the surrounding environment, indicating contamination by these elements in the studied areas. Guo et al. (2020) also reported that Cd contamination in rice grains was higher in the Jin-Qu Basin than in other cultivation areas, which nonferrous metal plants could influence. This similar condition could account for the high $\mathrm{Cd}$ content of rice from Ha Tinh province. Ky Anh is home to the Vung Ang industrial zone, which includes a thermal power plant and a steel factory, and the industrial activities in that area may result in high $\mathrm{Cd}$ levels in rice. On the other hand, $\mathrm{Pb}$ could be introduced into rice grains through atmospheric deposition during metal-mining activities via dust and particulate material deposition. Other studies have discovered that $\mathrm{Cd}$ and $\mathrm{Pb}$ quickly transfer from soils, particularly in mining areas, and accumulate in vegetables and rice (Zhuang et al., 2009; Bui et al., 2016; Mao et al., 2019).

\subsection{Daily intakes of trace elements via rice consumption and the risk to human health}

\subsubsection{Estimated dietary intake of trace elements}

Although there are numerous pathways through which humans can be exposed to trace elements, rice consumption has been identified as one of the major routes. This means that human exposure to these contaminants will increase as rice consumption increases in Vietnam. The non-carcinogenic and carcinogenic health risk assessments of trace elements can be calculated and evaluated using the method of health risk assessment provided by the US EPA (US EPA, 2021). Table 2 depicts the dietary intake of trace elements from rice consumption for adults (both male and female) and children (including boys and girls under the age of five), assuming that the local population primarily consumes local rice. 
Table 2

Estimated daily intakes (EDI) of heavy metaltrace elements from rice for adults and children (under 5 yearfive years old). The values are expressed as the average \pm standard deviation

\begin{tabular}{|c|c|c|c|c|}
\hline \multicolumn{2}{|c|}{ Location } & \multirow{2}{*}{$\begin{array}{l}\text { Thanh Hoa } \\
1.66 \pm 0.58\end{array}$} & \multirow{2}{*}{$\begin{array}{l}\text { Ha Tinh } \\
0.16 \pm 0.03\end{array}$} & \multirow{2}{*}{$\begin{array}{l}\text { Nghe An } \\
0.20 \pm 0.02\end{array}$} \\
\hline $\mathrm{Cr}$ & Male & & & \\
\hline & Female & $1.96 \pm 0.67$ & $0.18 \pm 0.03$ & $0.24 \pm 0.02$ \\
\hline & Baby boy & $3.78 \pm 1.33$ & $0.34 \pm 0.05$ & $0.45 \pm 0.05$ \\
\hline & Baby girl & $4.07 \pm 1.43$ & $0.37 \pm 0.06$ & $0.49 \pm 0.05$ \\
\hline \multirow[t]{4}{*}{$\mathrm{Ni}$} & Male & $1.23 \pm 0.30$ & $1.35 \pm 0.32$ & $1.17 \pm 0.26$ \\
\hline & Female & $1.45 \pm 0.35$ & $1.60 \pm 0.38$ & $1.34 \pm 0.33$ \\
\hline & Baby boy & $2.80 \pm 0.68$ & $3.08 \pm 0.73$ & $2.67 \pm 0.60$ \\
\hline & Baby girl & $2.91 \pm 0.84$ & $3.32 \pm 0.79$ & $2.88 \pm 0.65$ \\
\hline \multirow[t]{4}{*}{ As } & Male & $0.95 \pm 0.14$ & $0.76 \pm 0.07$ & $0.76 \pm 0.12$ \\
\hline & Female & $1.12 \pm 0.16$ & $0.90 \pm 0.09$ & $0.87 \pm 0.14$ \\
\hline & Baby boy & $2.16 \pm 0.31$ & $1.73 \pm 0.17$ & $1.74 \pm 0.27$ \\
\hline & Baby girl & $2.33 \pm 0.33$ & $1.89 \pm 0.18$ & $1.87 \pm 0.29$ \\
\hline \multirow[t]{4}{*}{$\mathrm{Cd}$} & Male & $0.08 \pm 0.03$ & $0.48 \pm 0.08$ & $0.27 \pm 0.10$ \\
\hline & Female & $0.09 \pm 0.03$ & $0.57 \pm 0.10$ & $0.31 \pm 0.11$ \\
\hline & Baby boy & $0.17 \pm 0.06$ & $1.09 \pm 0.18$ & $0.61 \pm 0.22$ \\
\hline & Baby girl & $0.19 \pm 0.06$ & $1.18 \pm 0.20$ & $0.66 \pm 0.23$ \\
\hline \multirow[t]{4}{*}{$\mathrm{Pb}$} & Male & $0.13 \pm 0.07$ & $0.06 \pm 0.01$ & $0.05 \pm 0.01$ \\
\hline & Female & $0.15 \pm 0.09$ & $0.07 \pm 0.01$ & $0.06 \pm 0.01$ \\
\hline & Baby boy & $0.30 \pm 0.16$ & $0.13 \pm 0.03$ & $0.11 \pm 0.02$ \\
\hline & Baby girl & $0.32 \pm 0.18$ & $0.14 \pm 0.03$ & $0.12 \pm 0.02$ \\
\hline
\end{tabular}

$\mathrm{EDI}$ trends for trace elements in rice were in the order of $\mathrm{Cr} \otimes \mathrm{Ni} \otimes \mathrm{As} \otimes \mathrm{Pb} \otimes \mathrm{Cd}$. The highest EDI of $\mathrm{Cr}$ (4.1 $\left.\mu \mathrm{g} \mathrm{d}^{-1}\right)$ in Thanh Hoa, Ni $\left(3.3 \mu \mathrm{g} \mathrm{d}^{-1}\right)$ in Ha Tinh, As $\left(2.3 \mu \mathrm{g} \mathrm{d}^{-1}\right)$ in Thanh Hoa, $\mathrm{Cd}\left(1.2 \mu \mathrm{g} \mathrm{d}^{-1}\right)$ in Ha Tinh, and $\mathrm{Pb}\left(0.49 \mu \mathrm{g} \mathrm{d}^{-1}\right)$ in Nghe An were observed. Among the investigated population groups, the baby group was estimated to have the highest intake of all five trace elements via consumption of about $205 \mathrm{~g}$ rice day ${ }^{-1}$. Because of the bodyweight effect, males $\left(59.4 \mathrm{~kg}\right.$ ) with rice consumption of $325 \mathrm{~g} \mathrm{day}^{-1} \mathrm{had}^{-}$ the lowest EDI values. The EDIs for $\mathrm{Cr}$, As, and $\mathrm{Cd}$ from rice consumption in both adults and children under five years old in this study are higher than those in the Yangtze River Delta, China (Hang et al., 2009; Mao et al., 2019), but lower than those in the mining areas of the Jin-Qu Basin (Guo et al., 2020) 
and Dabaoshan mine (Zhuang et al., 2009). On the other hand, the present data showed that the average $\mathrm{EDI}$ values for $\mathrm{As}, \mathrm{Cr}, \mathrm{Ni}$, and $\mathrm{Pb}$ in the adult group from three studied provinces were higher than those found in the Red River Delta (Chu et al., 2021).

The lower EDIs in the adult group than the children group (under five years old) in this study are consistent with previous findings (Nguyen et al., 2021; Hang et al., 2009; Mao et al., 2019; Zheng et al., 2007). Even though rice consumption is very high in Vietnam, the EDI values for all trace elements for adults and children are lower than the RfD. In China, daily rice consumption ranged between 238 - $389 \mathrm{~g}$ person $^{-1}$ day $^{-1}$ (Hang et al., 2009; Guo et al., 2020; Mao et al., 2019) for adults, with children consuming $198 \mathrm{~g} \mathrm{person}^{-1}$ day $^{-1}$ (Hang et al., 2009; Mao et al., 2019), whereas Vietnamese adults and children under five years old consume 325 and $205 \mathrm{~g}_{\text {person }}{ }^{-1}$ day $^{-1}$, respectively. In addition, a previous study (Nguyen et al., 2021) discovered that the exposure dose of As from rice consumption varied across age groups and gender due to rice intake and body weight differences. According to the authors, females consumed more As than males, and children consumed more As than adults per day due to a higher rice intake/body weight ratio.

\subsubsection{Potential health risk of individual trace elements}

Although adults consume more rice than children, the THQ values of trace elements for adults were lower than those for children (Fig. 3). THQ values of As were the highest, exceeding 1, implying that people were exposed to health risks from consumption As contaminated rice. Furthermore, the levels of $\mathrm{Cd}$ and $\mathrm{Cr}$ in some sampling sites could pose health risks to rice consumers. For adults, the THQs from rice consumption are in decreasing order $\mathrm{As}>\mathrm{Cd}>\mathrm{Cr}>\mathrm{Ni}>\mathrm{Pb}$. THQs for children under five are comparable to those for adults. According to the current findings, As ingestion from rice poses the highest potential health risk for both adults and children under five groups, while Ni ingestion poses the least risk for the population studied. In this study, the differences in health risk between the three provinces were also compared. In general, Thanh Hoa had the highest THQs for studied elements, followed by Ha Tinh and Nghe An (Fig. 3). This result indicated that the inhabitants of Thanh Hoa suffered more adverse health effects as a result of consuming rice than residents of other provinces.

THQ values of As for adults in Thanh Hoa, Nghe An, and Ha Tinh were $3.1 \pm 0.45$ to $7.8 \pm 1.1,2.5 \pm 0.25$ to $6.2 \pm 0.68$, and $2.5 \pm 0.39$ to $6.3 \pm 0.96$, respectively (Fig. 3). THQs of As for children under five years old, particularly baby girls, were 2 to 2.5 times higher than adults, implying that rice consumption may pose serious health risks depending on gender and age group. The current study's As-THQs for adults and children were significantly higher than those in the Yangtze River Delta, which were 0.028 and 2.3 (Hang et al., 2009), and 0.024 and 2.7 (Mao et al., 2019), respectively. The discrepancy in THQ values could be attributed to THQ's effective parameters and their variations across geographic regions. Furthermore, children under five in Thanh Hoa and Ha Tinh may face higher health risks because of $\mathrm{Cr}$ and $\mathrm{Cd}$, respectively. In fact, this risk assessment was based not only on trace element levels in rice, but also on rice consumption rates. According to other studies, Vietnamese adults consume more rice $\left(325 \mathrm{~g} \mathrm{day}^{-1}\right)$ than their counterparts in China, Japan, and Taiwan $\left(238,119\right.$, and $132 \mathrm{~g} \mathrm{day}^{-1}$, respectively). Therefore, 
it can be explained that Vietnamese people primarily consume rice as a carbohydrate source, whereas wheat, buckwheat, and other grains are consumed in other Asian countries.

\subsubsection{Potential health risks of combined trace elements and Target cancer risks}

The $\mathrm{HI}$ was calculated by considering the cumulative effect of consuming five potentially hazardous elements from rice (Fig. 4). The calculated HI values range from 1.7 for males in Nghia Dan (Nghe An) to the highest value of about 11 for girls under five in Bim Son (Thanh Hoa). The current HI results were significantly higher than those in previous studies (Hang et al., 2009; Guo et al., 2020; Zheng et al., 2007; Antoine et al., 2017). The HI trends were as follows: Bim Son > Nghi Son > Ky Anh > Hung Nguyen Thanh Chuong > Quang Xuong > Nghi Xuan Do Luong > Duc Tho > Nghia Dan. According to our findings, As is a key component contributing to the potential health risk of non-carcinogenic effects in adults and children, with $\mathrm{Cr}$ and $\mathrm{Cd}$ serving as secondary components.

Because $\mathrm{Cr}$ and $\mathrm{Ni}$ are essential micronutrients for human health, moderate levels of $\mathrm{Cr}$ and $\mathrm{Ni}$ found in rice samples may pose a significant health risk (Uriu-Adams and Keen, 2005). Many studies have found that people are exposed to metals through other foods such as wheat, vegetables, fruit, fish, meat, eggs, water, and milk (Bui et al., 2016; Zheng et al., 2007; Antoine et al., 2017). However, Asians consume much rice on a daily basis; therefore, rice is a significant pathway for local people's dietary exposure to metals or toxic elements through food. Hence, local inhabitants need to reduce their rice consumption and diversify their diets to reduce the health risks associated with dietary Cd and As intake. It is noteworthy that this study did consider special groups, such as women and children under the age of five, who are presumably more vulnerable to pollutants with both non-carcinogenic and carcinogenic effects.

Furthermore, the fact is that the average $\mathrm{HI}$ values for girls under five were 1.5 times higher than for other groups.

Only $\mathrm{Ni}$ and Pb were considered for target cancer risk (TR) assessment in this study (Table 3, Fig. 5). TR values for $\mathrm{Ni}$ and $\mathrm{Pb}$ ranged from $4.29 \times 10^{-7}$ to $3.03 \times 10^{-3}$, indicating a potential carcinogenic risk to rice consumers in most investigated areas, particularly Ha Tinh and Thanh Hoa (Table 3), with Ni showing the highest cancer risk $\left(\mathrm{TR}>1 \times 10^{-3}\right)$. In Ha Tinh, the risks come from Ni for adults and children under five years old were $1.45 \times 10^{-3}$ (female) and $3.03 \times 10^{-3}$ (girls under five years old), implying that 145 per 100,000 adults and 303 per 100,000 baby girls under five years old are at the highest risk of cancer caused by $\mathrm{Ni}$ intake from rice. Following publications that used $10^{-6}$ to $10^{-4}$ as the range for acceptable risk of developing cancer (Antoine et al., 2017; Shaheen et al., 2016), 10-4 was accepted as the upper limit. In this study, high cancer risk would be expected to be associated with Ni (Fig. 5; Table 3). The cancer risk calculated for $\mathrm{Pb}$ was within the low or acceptable range of $10^{-7}$ to $10^{-5}$, indicating that the cancer risk from $\mathrm{Pb}$-contaminated rice consumption in the three provinces studied was tolerable. However, the total cancer risk (TCR) analysis revealed the potential adverse cancer risk induced by $\mathrm{Ni}$ and $\mathrm{Pb}$ from rice consumption, as the TCR values were significantly higher than the threshold level $\left(>10^{-6}\right)$ at all sampling sites. 
Table 3

Target cancer risk (TR) of trace elements from rice consumption in adults and children (under five years old). TR $<1 \times 10^{-6}$, insignificant risk; $1 \times 10^{-6}$ $<\mathrm{TR}<1 \times 10^{-4}$, low or acceptable risk range; and 1 $\times 10^{-3}<\mathrm{TR}<1 \times 10^{-1}$, high cancer risk levels

\begin{tabular}{|c|c|c|c|}
\hline & Groups & $\mathrm{Ni}$ & $\mathrm{Pb}$ \\
\hline \multirow[t]{4}{*}{ Thanh Hoa } & Male & $1.12 \mathrm{E}-03$ & 1.11E-06 \\
\hline & Female & 1.32E-03 & $1.31 \mathrm{E}-06$ \\
\hline & Baby boy & $2.55 \mathrm{E}-03$ & $2.53 \mathrm{E}-06$ \\
\hline & Baby girl & 2.75E-03 & $2.73 \mathrm{E}-06$ \\
\hline \multirow[t]{4}{*}{ Ha Tinh } & Male & 1.23E-03 & $5.00 \mathrm{E}-07$ \\
\hline & Female & 1.45E-03 & 5.91E-06 \\
\hline & Baby boy & 2.80E-03 & $1.14 \mathrm{E}-06$ \\
\hline & Baby girl & 3.03E-03 & $1.23 \mathrm{E}-06$ \\
\hline \multirow[t]{4}{*}{ Nghe An } & Male & 1.07E-03 & 4.29E-07 \\
\hline & Female & $1.22 \mathrm{E}-03$ & $4.86 \mathrm{E}-07$ \\
\hline & Baby boy & 2.43E-03 & 9.77E-07 \\
\hline & Baby girl & 2.62E-03 & $1.05 \mathrm{E}-06$ \\
\hline
\end{tabular}

In summary, the findings indicated a significant human health risk (both non-carcinogenic and carcinogenic) associated with the consumption of rice grown in most of the studied areas. As a result, strict regulatory control over the safety of vegetables originating in North-Central Vietnam should be implemented.

\section{Conclusion}

The current study found that mining and industrial activities were highly correlated with high $\mathrm{Cr}, \mathrm{Ni}, \mathrm{As}$, $\mathrm{Cd}$, and $\mathrm{Pb}$ in rice, posing significant health risks to the consumers. The risk estimation of the dietary intake of trace elements in the order of $\mathrm{Cr} \otimes \mathrm{Ni} \otimes \mathrm{As} \otimes \mathrm{Pb} \otimes \mathrm{Cd}$ suggested that rice consumption poses high health threats to the local population. Although the EDIs for all trace elements are all below the RfD for adults and children under the age of five in three provinces (Thanh Hoa, Nghe An, and Ha Tinh), the HI values range from 2.4 to 11, indicating that all groups of inhabitants may experience some adverse health effects. According to the cancer risk threshold, people were exposed to health risks primarily due to high $\mathrm{Cr}, \mathrm{Ni}$, and As levels.

\section{Declarations}




\section{Author Contributions:}

Thao L.T.: Investigation, Methodology, Writing original draft-Review \& Editing. Kim K.W.: Resource, Validation. Dinh N.Q.: Validation, Conceptualization. Huong N.T.T.: Conceptualization, Methodology, Writing-Review \& Editing, Supervision. All authors have read and agreed to the published version of the manuscript.

Acknowledgement: This research is partly funded by Internship Program for Ms. Nguyen Quynh from International Environmental Research Institute (IERI) at Gwangju Institute of Science and Technology (GIST) in spring 2020. We'd also like to thank our students, Phong and Tung, for assisting us with the rice sample collection and processing. We are grateful to Ms. Nguyen Quynh Anh from Vietnam Institute of Geosciences and Mineral Resources and Ms. Eunkyung Cho from Gwangju Institute of Science and Technology for their contributions in measuring trace elements from rice samples.

Competing Interests: The authors have no relevant financial or non-financial interests to disclose

Data Availability Statement: The datasets used in this study are available from the corresponding author on reasonable request

Conflicts of Interest: The authors declare no conflict of interest

Ethical approval: This article does not contain any studies with human participants or animals performed by any of the authors.

\section{References}

1. Antoine, J. M. R., Fung, L. A. H., \& Grant, C. N. (2017). Assessment of the potential health risks associated with the aluminium, arsenic, cadmium and lead content in selected fruits and vegetables grown in Jamaica. Toxicol Rep, 4 181-187.10.1016/j.toxrep.2017.03.006

2. Azam, S. M. G. G., Sarker, T. C., \& Naz, S. (2016). Factors affecting the soil arsenic bioavailability, accumulation in rice and risk to human health: a review. Toxicology Mechanisms and Methods, 26 (8), 565-579.10.1080/15376516.2016.1230165

3. Bui, A. T. K., Duong, L. T., \& Nguyen, M. N. (2020). Accumulation of copper and cadmium in soil-rice systems in terrace and lowland paddies of the Red River basin, Vietnam: the possible regulatory role of silicon. Environmental Geochemistry and Health, 42 (11), 3753-3764.10.1007/s10653-020-00626y

4. Bui, A. T., Nguyen, H. T., Nguyen, M. N., Tran, T. H., Vu, T. V., Nguyen, C. H., \& Reynolds, H. L. (2016). Accumulation and potential health risks of cadmium, lead and arsenic in vegetables grown near mining sites in Northern Vietnam. Environ Monit Assess, 188 (9), 525.10.1007/s10661-016-5535-5

5. Chen, Q. Y., DesMarais, T., \& Costa, M. (2019). Metals and Mechanisms of Carcinogenesis. Annu Rev Pharmacol Toxicol, 59 537-554.10.1146/annurev-pharmtox-010818-021031 
6. Chien, L. C., Hung, T. C., Choang, K. Y., Yeh, C. Y., Meng, P. J., Shieh, M. J., \& Ha, B. C. (2002). Daily intake of TBT, Cu, Zn, Cd and As for fishermen in Taiwan. Sci Total Environ, 285 (1-3), 177185.10.1016/s0048-9697(01)00916-0

7. Chu, D. B., Duong, H. T., Nguyet Luu, M. T., Vu-Thi, H. A., Ly, B. T., \& Loi, V. D. (2021). Arsenic and Trace elements in Vietnamese Rice: Assessment of Human Exposure to These Elements through Rice Consumption. Journal of Analytical Methods in Chemistry, 2021 6661955.10.1155/2021/6661955

8. Fan, Y., Zhu, T., Li, M., He, J., \& Huang, R. (2017). Heavy Metal Contamination in Soil and Brown Rice and Human Health Risk Assessment near Three Mining Areas in Central China. J Healthc Eng, 2017 4124302-4124302.10.1155/2017/4124302

9. FAO, FAOSTAT - Food Balances (2010). -) (2021, December 24) [https://www.fao.org/faostat/en/\#data/FBS]

10. Guo, B., Hong, C., Tong, W., Xu, M., Huang, C., Yin, H. ... Fu, Q. (2020). Health risk assessment of heavy metal pollution in a soil-rice system: a case study in the Jin-Qu Basin of China. Scientific Reports, 10 (1), 11490.10.1038/s41598-020-68295-6

11. Hang, X., Wang, H., Zhou, J., Ma, C., Du, C., \& Chen, X. (2009). Risk assessment of potentially toxic element pollution in soils and rice (Oryza sativa) in a typical area of the Yangtze River Delta. Environ Pollut, 157 (8-9), 2542-2549.10.1016/j.envpol.2009.03.002

12. Huang, S. S., Liao, Q. L., Hua, M., Wu, X. M., Bi, K. S., Chen, Y. C. Y., \& Zhang, B. (2007). X. Y. Survey of heavy metal pollution and assessment of agricultural soil in Yangzhong district, Jiangsu Province, China. Chemosphere, 67 (11), 2148-2155. https://doi.org/10.1016/j.chemosphere.2006.12.043

13. Joint, F. A. O. W. H. O. (2019). Food Standards Program, Codex alimentarius, standard for rice, (Amended in ; Accessed on 2021, December 24) [https://www.fao.org/fao-whocodexalimentarius/codex-texts/all-standards/en/]

14. Khôi, N. N. Í. (2014). Mineral Resources Potential of Vietnam and Current State of Mining Activity. Applied Environmental Research, 36, 37-46

15. Kien, C. N., Noi, N. V., Son, L. T., Ngoc, H. M., Tanaka, S., Nishina, T., \& Iwasaki, K. (2010). Heavy metal contamination of agricultural soils around a chromite mine in Vietnam. Soil Science and Plant Nutrition, 56 (2), 344-356.10.1111/j.1747-0765.2010.00451.x

16. Mao, C., Song, Y., Chen, L., Ji, J., Li, J., Yuan, X.... Theiss, F. (2019). Human health risks of trace elements in paddy rice based on transfer characteristics of trace elements from soil to rice. CATENA, 175, 339-348. .https://doi.org/10.1016/j.catena.2018.12.029

17. National Institute of Nutrition, UNICEF-Viet Nam (Accessed in 2012). December 2021)., A review of the Nutrition situation in Vietnam 2009-2010 [http://viendinhduong.vn/en/nutrition-database/areview-of-the-nutrition-situation-in-vietnam-2009-2010.html]

18. Nguyen, H. P. A., Cu, Y. H., Watchalayann, P., \& Soonthornchaikul, N. (2021). Assessing inorganic arsenic in rice and its health risk to consumers in Ho Chi Minh City, Vietnam. Journal of Health Research, 35 (5), 402-414.10.1108/JHR-09-2019-0221 
19. Nguyen, T. H., Sakakibara, M., Sano, S., \& Mai, T. N. (2011). Uptake of metals and metalloids by plants growing in a lead-zinc mine area, Northern Vietnam. J Hazard Mater, 186 (2-3), 13841391.10.1016/j.jhazmat.2010.12.020

20. Qu, M., Li, W., Zhang, C., Huang, B., \& Zhao, Y. (2015). Assessing the pollution risk of soil Chromium based on loading capacity of paddy soil at a regional scale. Scientific Reports, 5 (1), 18451.10.1038/srep18451

21. Rodriguez, L., Rincón, J., Asencio, I., \& Rodríguez-Castellanos, L. (2007). Capability of selected crop plants for shoot mercury accumulation from polluted soils: phytoremediation perspectives. Int $J$ Phytoremediation, 9 (1), 1-13.10.1080/15226510601139359

22. Shaheen, N., Ahmed, M. K., Islam, M. S., Habibullah-Al-Mamun, M., Tukun, A. B., \& Islam, S. (2016). AT M. A. R. Health risk assessment of trace elements via dietary intake of 'non-piscine protein source' foodstuffs (meat, milk and egg) in Bangladesh. Environ Sci Pollut Res Int, 23 (8), 77947806.10.1007/s11356-015-6013-2

23. Shimbo, S., Zhang, Z. W., Watanabe, T., Nakatsuka, H., Matsuda-Inoguchi, N., Higashikawa, K., \& Ikeda, M. (2001). Cadmium and lead contents in rice and other cereal products in Japan in 19982000. Sci Total Environ, 281 (1-3), 165-175.10.1016/s0048-9697(01)00844-0

24. Sridhara Chary, N., Kamala, C. T., \& Suman Raj, S. D (2008). Assessing risk of trace elements from consuming food grown on sewage irrigated soils and food chain transfer. Ecotoxicology and Environmental Safety, 69(3), 513-524. https://doi.org/10.1016/j.ecoenv.2007.04.013

25. Tran, C. T., Le, T. T., Duong, L. T., Dultz, S., \& Nguyen, M. N. (2020). A comparative study of arsenic in rice in lowland and terraced paddies in the Red River Basin. Vietnam. Land Degradation \& Development, 31(17), 2635-2647. https://doi.org/10.1002/ldr.3638

26. Uriu-Adams, J. Y., \& Keen, C. L. (2005). Copper, oxidative stress, and human health. Mol Aspects Med, 26 (4-5), 268-298.10.1016/j.mam.2005.07.015

27. US EPA (2014). (2021, December 24). EPA Region 3 Risk-based Concentration Table. [https://cfpub.epa.gov/ncea/iris/search/index.cfm]

28. US EPA, (released in (November 2021). Accessed on December 24, 2021). Regional screening level (RSL) summary table. [https://www.epa.gov/risk/regional-screening-levels-rsls-generic-tables]

29. Xiao, L., Guan, D., Peart, M. R., Chen, Y., Li, Q., \& Dai, J. (2017). The influence of bioavailable trace elements and microbial parameters of soil on the metal accumulation in rice grain. Chemosphere, 185 868-878.10.1016/j.chemosphere.2017.07.096

30. Xu, X. Y., McGrath, S. P., Meharg, A. A., \& Zhao, F. J. (2008). Growing Rice Aerobically Markedly Decreases Arsenic Accumulation. Environmental Science \& Technology, 42 (15), 55745579.10.1021/es800324u

31. Zarcinas, B. A., Ishak, C. F., McLaughlin, M. J., \& Cozens, G. (2004). Trace elements in soils and crops in Southeast Asia. 1. Peninsular Malaysia. Environ Geochem Health, 26 (4), 343357.10.1007/s10653-005-4669-0 
32. Zheng, N., Wang, Q., Zhang, X., Zheng, D., Zhang, Z., \& Zhang, S. (2007). Population health risk due to dietary intake of trace elements in the industrial area of Huludao City, China. Sci Total Environ, 387 (1-3), 96-104.10.1016/j.scitotenv.2007.07.044

33. Zhuang, P., McBride, M. B., Xia, H., Li, N., \& Li, Z. (2009). Health risk from trace elements via consumption of food crops in the vicinity of Dabaoshan mine, South China. Science of The Total Environment, 407(5), 1551-1561. https://doi.org/10.1016/j.scitotenv.2008.10.061

\section{Figures}

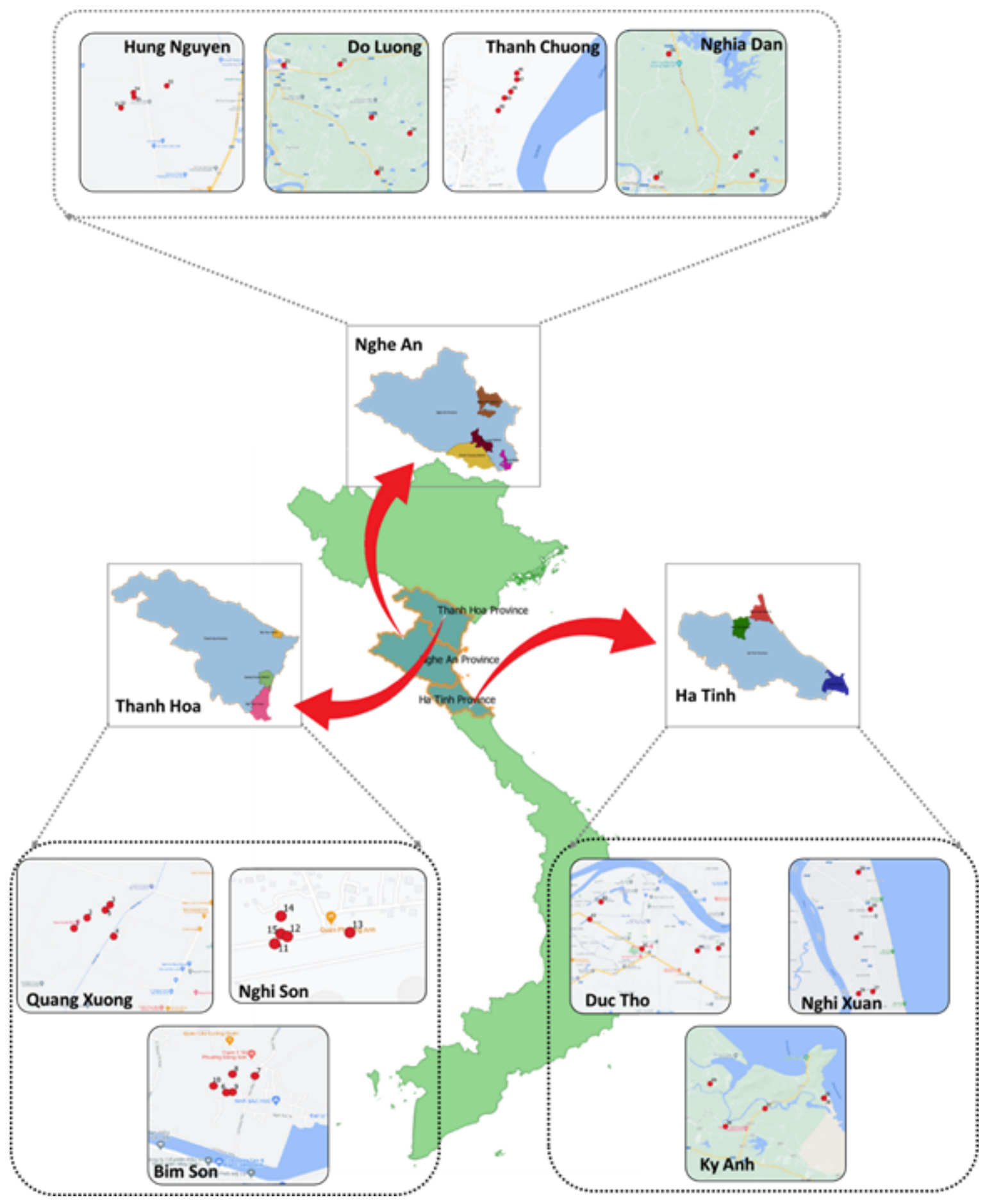


Figure 1

Sampling sites in Thanh Hoa, Ha Tinh and Nghe An provinces. (1) Industrial zones: Bim Son, Nghi Son, Ky Anh and Hung Nguyen; (2) Mining region: Quang Xuong, Bim Son, Ky Anh and Nghi Xuan; and (3) regions without industrial activities: Quang Xuong, Thanh Chuong, and Nghia Dan.

\section{Figure 2}

Average concentrations of $\mathrm{Cr}, \mathrm{Ni}, \mathrm{Cd}, \mathrm{Pb}$, and $\mathrm{As}$ in rice $\left(\mathrm{mg} \mathrm{kg}^{-1}\right.$ dried weight - $\mathrm{dw}$ ) collected from ten districts in three north-central provinces of Vietnam. QX: Quang Xuong, BS: Bim Son, NS: Nghi Son ND: Nghia Dan, DL: Do Luong, HN: Hung Nguyen, TC: Thanh Chuong, NX: Nghi Xuan, DT: Duc Tho, KA: Ky Anh.

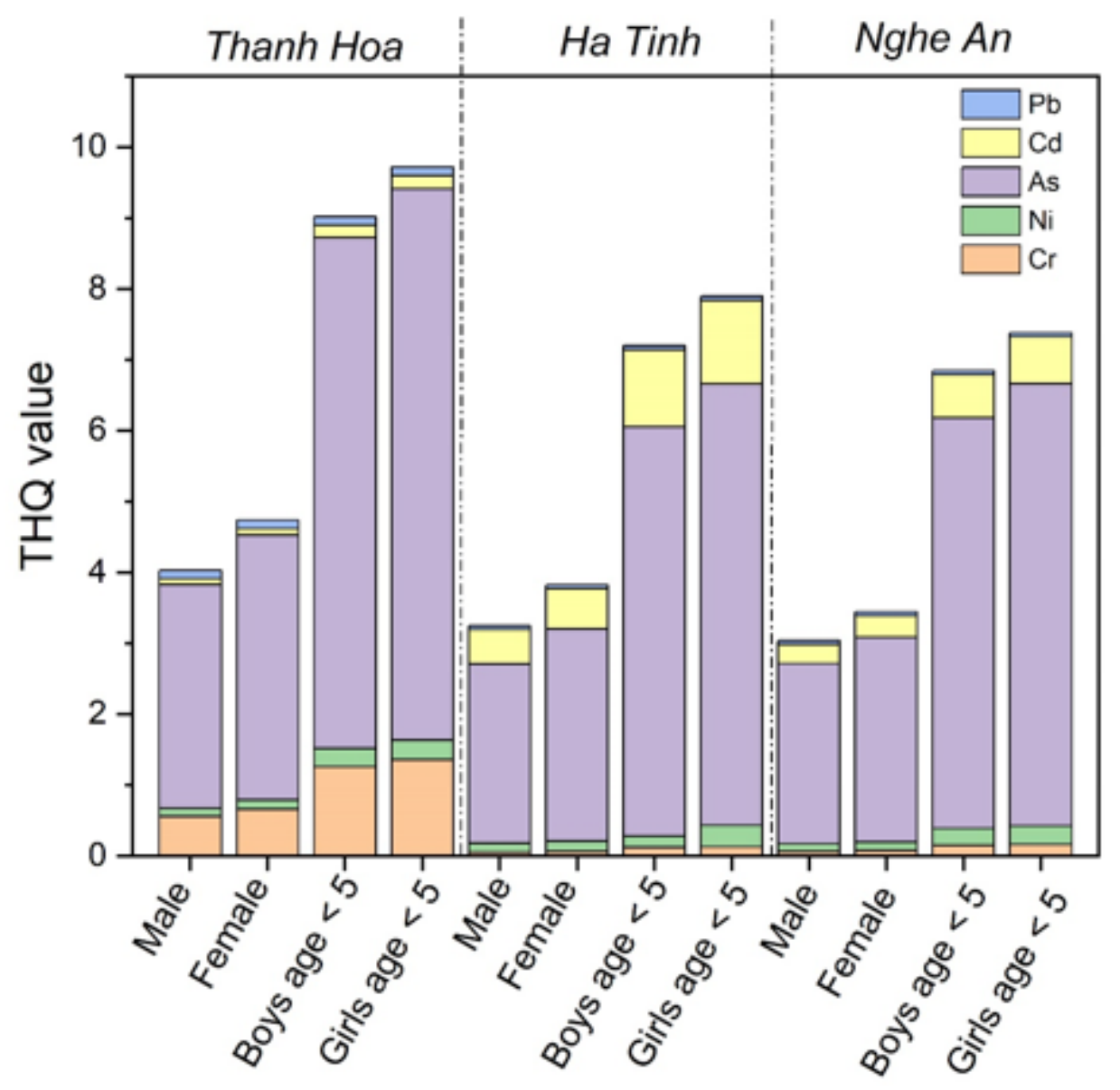

Figure 3

The spatial target hazard quotients (THQs) of five trace elements derived from rice consumption for adults and children (under 5-year-old). 


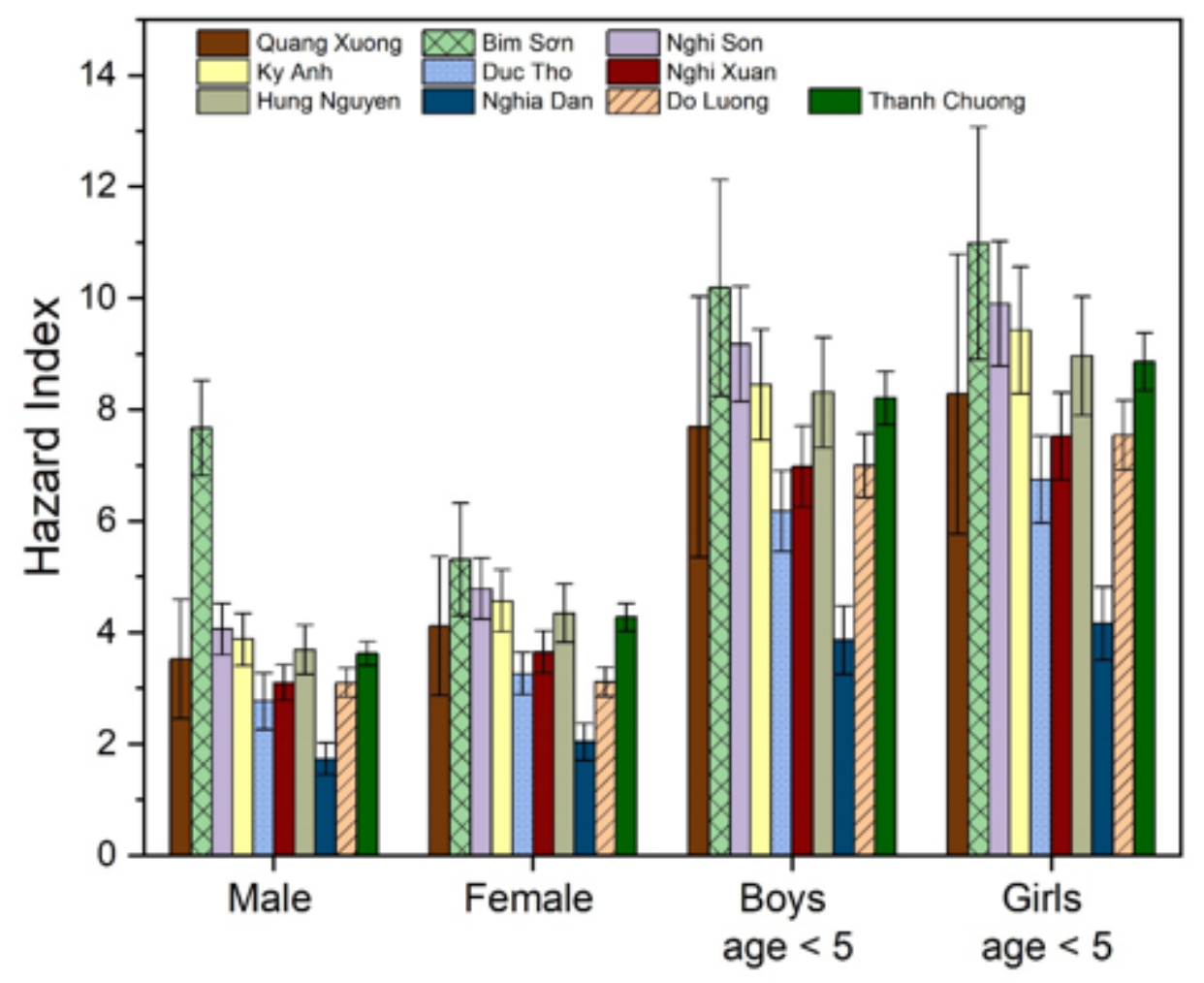

Figure 4

Non-cancer risks to human health of trace elements due to rice consumption in Thanh Hoa, Nghe An and Ha Tinh.

\section{Figure 5}

The average values for the target cancer risk (TR) posed by (a) $\mathrm{Ni}$ and (b) $\mathrm{Pb}$ due to rice consumption. TR $<1 \times 10^{-6}$, insignificant risk; $1 \times 10^{-6}<\mathrm{TR}<1 \times 10^{-4}$, low or acceptable risk range; and $1 \times 10^{-3}<\mathrm{TR}<1 \times$ $10^{-1}$, high cancer risk level. 